\title{
ÉLELMISZERPAZARLÁS ÉS MENTÉS MAGYARORSZÁGON
}

\author{
Makányné Kis Emese - Gál József
}

\begin{abstract}
Absztrakt: A szakdolgozatomban feltérképeztem világunk egyik legnagyobb ellentmondását, az éhezés és az élelmiszerpazarlást. Utánajártam az élelmiszer mentésnek is, az élelmiszerbankok müködésébe is betekintést nyertem. A kérdőíves kutatásomban bebizonyosodott, hogy iskolánk tanulói átlagos mértékben pazarolnak, közepesen tájékozottak az éhezés témájában és, hogy a tudatos fogyasztói magatartást tartják a probléma megoldásának. Szakdolgozatom legfontosabb következtetése az, hogy az élelmiszerpazarlás elkerülése érdekében a legjobb, amit tehetünk, ha megelőzzük azt. Ennek módja a tudatos fogyasztóvá válás, amelynek kialakulásához szemléletváltás szükséges a felnőttek körében, a gyermekeknél padig beépíthető a mindennapokba, életük részévé válik, így ez a globális probléma nagyobb mértékű csökkenése várható.
\end{abstract}

\begin{abstract}
In my thesis is I investigated one of the biggest contradictions in our world, starvation and food waste. I looked into the process of food rescue and I gained an insight into the operation of food banks. In my questionnaire research I have shown that our school's students waste food on an average level and are moderately informed about the topic of starvation. In their opinion, the solution to the problem would be the conscious consumer behaviour. The main conclusion of my thesis is that the best thing we can do to prevent food waste is to prevent it. The way to do this is to become a conscious consumer, which requires a change of attitude among adults. This consumer awareness and change of attitude can be integrated into the everyday life of children, becoming a part of their lives, and thus a greater reduction in the global problem might be expected.
\end{abstract}

Kulcsszavak: élelmiszerpazarlás, éhezés, élelmiszermentés, tudatosság, megelözés, környezetvédelem

Keywords: food waste, hunger, food saving, awareness, prevention, environmental protection

\section{Bevezetés}

Kutatásom célja a figyelemfelkeltés, mert témája érdekes, globális, sokrétủ, aktuális, és sürgős megoldásra váró probléma. A világ egyik legnagyobb ellentmondása: míg a földünk egyik részén több milliárd ember éhezik, addig a másik részén óriási mennyiségü élelmiszer kerül elöállításra (Zsótér-Túri, 2017) és ennek jelentős része a szemetesekbe. Ezek az élelmiszerek hol keletkeznek legnagyobb mennyiségben? Mi lehet az oka, hogy ezen élelmiszerek nem juthatnak el oda, ahol szükség lenne rájuk? A világ népességének növekedésével az éhezés is növekszik majd? Hogyan tudnánk csökkenteni az elpazarolt élelmiszerek mennyiségét? Ilyen és ehhez hasonló kérdések merültek fel bennem, és most ezekre keresem a választ.

Úgy gondoltam feltérképezem az éhezés mértékét, és okát a világban és Magyarországon is. Ezután megnézném a másik oldalt is a pazarlás mértékét, és azt hogy hol és milyen arányban keletkeznek kidobásra ítélt élelmiszerek. Kiskunfélegyházán egy szakközépiskolában dolgozom szakoktatóként, és nagyon kíváncsi lettem mit gondol ebben a témában a szakközépiskolás korosztály, így kérdőíves kutatást végeztem körükben. Az élelmiszerpazarlás csökkentésére vártam tőlük ötleteket.

Egyre többet hallhatunk már Magyarországon is az élelmiszermentésről, így szakdolgozatomban az Élelmiszerbank munkáját és az egyéb élelmiszermentési módszereket is vizsgálom. 


\section{Szakirodalmi áttekintés}

Körülbelül 150 millió fejlödésben visszamaradt gyermek él ma a világon, és folyamatosan emelkedik az éhező emberek száma, ami 2017-re már elérte a 821 milliót. Ez annyit jelent, hogy minden kilencedik ember éhínségben szenved - jelenti az ENSZ.

Nagyon nagy ellentmondás az is, hogy míg az éhezők száma nem csökken, a fejlett országokban ugyanekkora probléma a túlsúlyos emberek növekvő száma, minden nyolcadik ember túlsúlyos. (https:unicef.hu/igy-segitunk/hireink-a-vilagonminden-kilencedik-ember-ehezik, 2019.02.10.)

Magyarországon is jelen van az éhezés. Az éhezés oka a szegénység. Magyarországon a KSH adatai szerint 7 év alatti gyerekek 42,2 \%-a él szegénységben. 41 fejlett országból hazánk a 32 helyen áll ebben. (merce.hu/2018/09/09eheznek-a-gyerekek-es-eznem-a-szulok-gondatlansagaelsosorban, 2019.02.10.)

A FAO adatai alapján a Föld országaiban a legyártott, megtermelt élelmiszerek több mint $30 \%$-a válik hulladékká. Ennek a mennyiségnek fele elegendő lenne ahhoz, hogy az éhezés megszünjön.

Ez a hulladék keletkezhet az élelmiszerek gyártása során, a kereskedelemben és a háztartásokban. Fejlettebb országokban a legnagyobb mennyiségü hulladékot a háztartások termelik, míg a fejletlenebb országokban a gyártás és a szállítás miatt keletkezik a legtöbb kidobásra ítélt élelmiszer. Az Európai Unióban évente 90 millió tonna élelmiszer végzi a szemetesben.

Magyarországon a pazarlás csökkentésére a NÉBIH „Maradék nélkül”nevű programja próbálja felhívni a háztartások figyelmét.

2017. 06. 27-én a NÉBIH közétette egy 2016-ban végzett kutatás eredményét.

A 2016-os év végén indult program célja az élelmiszer hulladék keletkezésének megelőzése. A program feladata a vásárlói magatartás megváltoztatása, a fogyasztói szemlélet megváltoztatása, tudatos vásárlóvá válás segítése, ezáltal a szükségtelenül keletkező élelmiszer hulladék keletkezésének megakadályozása, vagy csökkentése. A kutatás két fő részből állt.

1. Az élelmiszerpazarlás okainak feltárása, 1002 fő bevonásával vizsgálták a témához kapcsolódó attitüdöket, a magatartási mintáikat, és a tudás szintjüket.

2. Megmérették 100 háztartás egy hét alatt keletkező élelmiszer hulladékát és elemzésnek vetették alá a mérési eredményeket.

Az élelmiszerpazarlás okai vizsgálatának eredménye:

A bevont emberek komoly problémának tekintik az élelmiszerpazarlást, de saját háztartásuk szintjén csak a válaszadók 37,8 \%-a gondolta végig mennyit pazarolhat egy év alatt.

A tudásszint mérés eredménye: A tudásszint Magyarországon közepesnek tekinthető. Kiderült egy súlyos félreértés is. A minőség megörzési idő és fogyaszthatósági idő fogalmát nem látják tisztán a megkérdezettek.

Az élelmiszermentés Magyarországon a Magyar Élelmiszerbank müködésével vette kezdetét 2005-ben. 
Az Élelmiszerbankok 100-nál is több kereskedőtől és gyártótól gyűjtik be, a bármilyen okból forgalomba hozni nem kívánt élelmiszereket. Ezeket 350 karitatív szervezeten keresztül az ország minden pontján élő 348.000 nélkülözőhöz juttatják el.

Munkájuk értéke felbecsülhetetlen. (https://www.elelmiszerbank.hu/CMS/GetFile.php?tk=Documents file\&id=26, 2019.03.16.)

\section{Anyag és módszer}

A kutatásom célja az volt, hogy a NÉBIH kutatásait összehasonlítsam a magyar társadalom egy teljesen átlagos csoportjának tagjaival.

A kérdőíveket abban az iskolában tanuló diákokkal töltettem ki, ahol öt éve tanítok, szakoktatóként. Ez a Kiskunhalasi Szakképzési Centrum Kiskunfélegyházi Kossuth Lajos Szakképző Iskolája és Kollégiuma.

A kérdöíves felmérés előtt igen fontos a kérdöív alapos megtervezése, a próbakitöltetés és ezt követően annak véglegesítése (Zsótér-Tóth, 2014). A kérdőíveket 2018. májusában töltötték ki a tanulók. Az osztályokat nem válogattam, van közöttük fiú és lány, szakközépiskolás és szakgimnazista. A kitöltők életkora 15 és 20 év között voltak.

A 11 kérdést tartalmazó kérdőívet kitöltettem 112 tanulóval. A szakdolgozatomban felmerülő témák (éhezés, pazarlás, megoldások) mindegyikére vonatkozó kérdések vannak a kérdőívben, mert kíváncsi voltam, hogyan vélekedik a témáról a tinédzser korosztály. A kérdőívek eredményeit magam számoltam össze, manuálisan.

\section{Eredmények}

1. A mi iskolánk nem egy reprezentatív iskola, viszonylag sok nehézsorsú tanuló jár hozzánk. A 2018-as tanév végi tanuló nyilvántartói adatok szerint: Iskolánk nappali tagozatos tanulóinak létszáma 643 fö, ebböl Hátrányos helyzetü:84 fö, Halmozottan hátrányos helyzetü:98 fö, Rendszeres Gyermekvédelmi támogatásban részesül:187 tanuló

Ezért a 112 kérdőív összesítésénél meglepve tapasztaltam, hogy a tanulók családi anyagi helyzetére vonatkozó kérdésre válaszolva csak egy tanuló vallotta magát nagyon szegénynek, és 12 tanuló szegénynek. Elgondolkodtam vajon mi lehet ennek az oka? Talán nem tudják mit is jelent pontosan a szegénység, vagy a közvetlen környezetükben mindenki ilyen helyzetben van, és ezt gondolják átlagosnak, általánosnak? Vagy csak egyszerüen szégyellik, hogy szegények? Ennek a témakörnek a kutatása a későbbiekben még előttem áll, kíváncsi lettem az okokra, megér egy komolyabb vizsgálatot a téma.

2. A Magyarországon 23,8\%-os tartósan éhezők arányát a 112 tanulóból csak 29 közelítette meg, a legtöbben ennél kevesebbre gondoltak, 12 tanuló pedig nem gondolkozott még el ezen. 
3. A világon élő éhezők számát már többen jól közelítették a valóságot, az egymilliárd körüli éhezők számát a válaszadók 33\%-a gondolta helyesnek

4. Arra a kérdésemre, hogy Mit gondol, 1 fö 1 év alatt mennyi élelmiszert pazarol?, a válaszadóknak csak a 11,6\%-a (13 fö) közelítette meg, a felmérésben látható 68,04 kilogrammot, a többiek mind kevesebbre gondoltak, legtöbben, 41,07\% (46 fö) az 50-60 kg közötti mennyiséget választotta. Ebből az látszik, nem is gondolják a tanulók, hogy milyen nagymértékü a pazarlás, és az ebböl fakadó globális probléma.

5. A „Maradék nélkül” program nem vizsgálta az élelmiszer kidobásának gyakoriságát, de az én kérdőívemben szerepel az a kérdés, hogy milyen gyakran dobnak ki élelmiszert a válaszadóim? A válaszadók 37,5\%-a (42fö) válaszolta, hogy egyáltalán nem dobnak ki élelmiszert, s ennél a kérdésnél már kirajzolódik, hogy iskolánk tanulóinak 28,03\%-a rendelkezik valamilyen hátrányos helyzettel, (hátrányos helyzet, vagy halmozottan hátrányos helyzet), így az ő szegénységükkel összefügghet, hogy ilyen sokan nem dobnak ki élelmiszert.

\section{1. ábra: Kidobott élelmiszerek gyakorisága}

\section{Ön vagy családja milyen gyakran dob ki élelmiszert?}

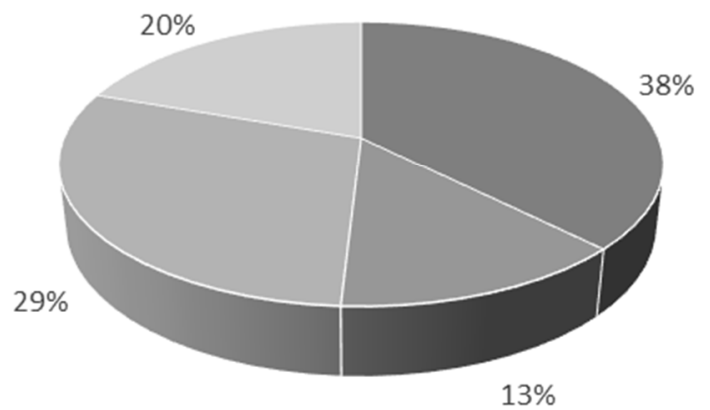

" nem dobunk ki élelmiszert " naponta " hetente " kéthetente, vagy annál ritkábban

Forrás: Szerzői felmérés alapján (2019)

6. Maradék nélkül" program eredményét, miszerint a készétel maradék kerül leggyakrabban a szemetesekbe. A NÉBIH felmérése szerint Magyarországon 40,8\%-a készétel maradék hulladék mennyisége, a tanulói kérdőív alapján $56,25 \%$, bár a százalék nem egyezik, de a legtöbben a készétel maradékot jelölték meg leggyakrabban kidobott élelmiszerként.

7. A kérdőívem utolsó kérdésére (11. kérdés) a tanulók kifejthették a véleményüket, hogy szerintük mire kellene figyelni az embereknek a pazarlás elkerülése érdekében? Itt nem soroltam fel lehetőségeket, amik közül választaniuk kellett, hanem pár sorban a saját véleményüket, 
gondolataikat írhatták le iskolánk tanulói. Ezeket a válaszokat is próbáltam összesíteni.

A kérdőívet kitöltők 60,71 \%-a, 68 tanuló válaszának lényege az volt, hogy arra kell leginkább odafigyelni, hogy csak annyi élelmiszert vásároljunk meg és készítsünk el, amennyit el is fogyasztunk. Tehát a tanulók szerint is a tudatos vásárlás a megelőzés legjobb módszere. Ezenkívül kiemelnék még a tanulók ötleteiből néhányat:

- Kisebb adagok vásárlása gyakrabban.

- Tudatosan táplálkozni.

- A hütőben található maradékot újragondolni és újrafelhasználni.

- A családok többször üljenek le együtt az asztalhoz, ne csak hétvégéken.

- Tartós élelmiszerek vásárlása.

- A romlandó élelmiszert csak akkor bontsuk fel, ha biztosan elfogyasztjuk.

- A hütőben a minőség megőrzési és fogyaszthatósági időt rendszeresen ellenőrizzük.

- Amit nem fogyasztunk el, juttassuk el rászorulókhoz, vagy komposztáljuk, ha lehetséges.

- Megfelelő étkezésre, mert a „magyar ember hajlamos „túlzásokba esni” az étkezést tekintve.

\section{Következtetés}

A szakirodalmakat tekintve is megállapítható, és a kérdöíves kutatásom is alátámasztja, hogy mindenképp a megelőzésben keresendő a megoldás kulcsa, a tudatos fogyasztói magatartás és az arra való nevelés a hosszú távú megoldás. Napjainkban sokat hallani a tudatos fogyasztásról, a fogalom összetett, nagyon sok mindent foglal magába.

A fogyasztóvédelmi megfogalmazás szerint tudatos az a fogyasztó, aki tisztában van a jogaival, tájékozódik a minőségről, árról, szolgáltatásokról, és ez alapján választja ki a számára legmegfelelőbb terméket.

Ma ennél többet kell, hogy jelentsen, hiszen magunkon kívül a jövő generációira is gondolnunk kell, gyermekeink, unokáink jövőjére is. Olyan fogyasztói döntést kell hoznunk, ahol már nem csak az számít, hogy mi jól járunk-e, hanem a világ jól járe. Gyakran halljuk, hogy „fogyasztói társadalom” vagyunk, ez azt jelenti, hogy a szükségestől többet vásárolunk, termékeink nem tartósak, ha elromlanak, nem javíttatjuk meg, kidobjuk, és újra vásárolunk.

A termékek értékén, értelmén is el kell gondolkodnunk, mit támogatunk egy-egy termék megvásárlásával, gyermekmunkát, környezetszennyezést, esetleg állatokon végzett kísérleteket? A kakaóbabot gyerekrabszolgák szüretelik, vagy egy márkás sportcipő kizsákmányoló munkakörnyezetben dolgozó emberek kezéből kerül hozzánk. A mi döntésünk, hogy kiválasztjuk-e?

Ökológiailag nem tartható, hogy a környezetből ennyi erőforrást kivegyünk. Az ökológiai katasztrófát leginkább a fejlett országok pazarló életmódja okozza, s lassan visszafordíthatatlanná válik. Az egyénenként hozott döntés, akarat összeadódik, 
mélyreható változást okozhat. A tudatos vásárlás elkötelezettség, és öröm egyaránt. (https://tudatosvasarlo.hu/tve/gyik, 2019.03. 25.)

A probléma megoldása tehát a megelőzés. Ahhoz, hogy ez a megelőző gondolkodásmód elterjedjen, alapos szemléletformálásra van szükség. Ezt érdemes gyermekkorban a szülőknek elkezdeni, de nagyon jól lehet iskolai kereteken belül is ilyen célú neveltetésben részesíteni a gyerekeket. A „Maradék nélkül” programnak része az iskolákban történő oktatás. Az iskoláskorú gyerekeknek szánt ismeretterjesztő kiadványban színes képekkel illusztrálva, könnyen elsajátítható módon teljes körü tájékoztatást kaphatnak a gyerekek a pazarlásról, annak a környezetkárosító hatásáról, és a lehetséges megoldásokról is, a komposztáláson át a tudatos vásárlói szokásokon keresztül az adományozásig. A füzetben minden témakör végén ellenörző kérdések vannak, játékosan sajátíthatják el e nagyon fontos globális probléma minden részletét. A szerzők kiemelik azt, hogy egy gyerek hogyan lehet ebben segítség. Mivel ma már a gyerekek élete a digitális eszközök nélkül elképzelhetetlen, így azok bevonásával is küzdhetünk a pazarlás ellen, különböző applikációk letöltésével, vagy akár a hütő tartalmának vásárlás elötti lefényképezésével, elkerülvén a felesleges élelmiszerek megvásárlását.

A program tehát összetett, a pazarlás elleni küzdelem összefogott, sokrétü, a tájékoztatáson és figyelemfelhíváson felül a megoldásokra is kínál sokféle lehetőséget. Az iskoláskorú gyerekek nyitottak a környezet védelmére (ami a tudatosságuk egy része), így a program nem véletlenül ezt a korosztályt célozza meg, hosszú távú célok elérése érdekében.

\section{Irodalomjegyzék}

<https://unicef.hu/igy-segitunk/hireink-a-vilagon-minden-kilencedik-ember-ehezik> (2019.02.10.)

<https://merce.hu/2018/09/09eheznek-a-gyerekek-es-eznem-a-szulok-gondatlansaga-elsosorban> (2019.02.10.)

<https://www.elelmiszerbank.hu/CMS/GetFile.php?tk=Documents__file\&id=26> (2019.03.16.) <https://tudatosvasarlo.hu/tve/gyik> (2019.03. 25.)

Zsótér B., Tóth A. (2014): Examination of satisfaction related to investments (2006-2011) accomplished by the local council in Abony. Review of Faculty of Engineering Analecta Technica Szegedinensia 8 (1): 33-37.

Zsótér B., Túri I. (2017): Economical calculations related to a smoking technology investment of a pork processing plant. Annals of Faculty of Engineering Hunedoara - International Journal of Engineering, 15 (4): 57-61. 